\title{
EDUKASI KESEHATAN REMAJA DI PANTI ASUHAN BINTANG TERAMPIL KOTA BENGKULU
}

\author{
${ }^{1}$ Oktarianita, ${ }^{2}$ Nurhayati, ${ }^{3}$ M. Amin \\ ${ }^{1,3,4)}$ Program Studi Kesehatan Masyarakat, Fakultas Ilmu Kesehatan, \\ Universitas Muhammadiyah Bengkulu \\ 2) Program Studi Ilmu Keperawtaan, Fakultas Ilmu Kesehatan, \\ Universitas Muhammadiyah Bengkulu \\ *Corresponding author: oktarianita@umb.ac.id
}

Informasi Artikel

Terima : 31/03/2021

Revisi : 22/05/2021

Disetujui : 12/08/2021

Kata Kunci: edukasi, kesehatan, remaja

\begin{abstract}
ABSTRAK
Kasus cedera pada anak usia sekolah dan remaja semakin meningkat. Masih kurangnya informasi mengenai kesehatan terutama untuk remaja. Perlu adanya pengetahuan dan pemahaman pada remaja terutama tentang berperilaku. Untuk itu, pendidikan kesehatan tentang kesehatan remaja menjadi langkah untuk meningkatkan pengetahuan dan pemahaman remaja tentang kesehatan remaja, terutama pada anak-anak sekolah. Sebab anak-anak merupakan kelompok rentan dan kecenderungan berperilaku berisiko mengalami permasalahan kesehatan. Pelaksanaan pengabdian kepada masyarakat yang akan dilaksanakan di Panti Asuhan Bintang Terampil menggunakan metode observasi, pendidikan kesehatan berupa penyuluhan. Observasi dilakukan untuk menentukan permasalahan apa yang dihadapi anak-anak, dilanjutkan kegiatan edukasi kesehatan remaja yang akhirnya akan berguna untuk menghadapi permasalahan kesehatannya. Dari observasi awal melalui wawancara terhadap 4 orang anak panti dengan beberapa pertanyaan mengenai pengetahuan tentang kesehatan remaja diketahui bahwa anak-anak belum mengetahui apa saja tentang kesehatan remaja. Hasil Tim Pengabdian Masyarakat setelah melakukan edukasi kesehatan remaja. Remaja mengetahui seputar kesehatan remaja, hal yang harus dihindari dan cara mengatasi masalah remaja. Kesimpulan dari hasil pengabdian ini kegiatan berjalan cukup baik, remaja telah mengetahui kesehatan remaja dan remaja antusias dalam mengikuti penjelasan yang diberikan.
\end{abstract}

PENDAHULUAN

Remaja adalah seseorang yang berusia antara 10-18 tahun, dan merupakan kelompok penduduk Indonesia dengan jumlah yang cukup besar (Kemenkes RI, 2019). Masa 
remaja merupakan suatu fase perkembangan antara masa kanak-kanak dan masa dewasa dimana seseorang akan mengalami banyak perubahan secara biologis, psikologis, maupun sosial. Beberapa masalah remaja antara lain, masih tingginya angka merokok pada remaja, mengkonsumsi alkohol, serta masalah Kesehatan terkait gizi remaja. Berdasarkan data Riskesdas, 2018 menunjukkan bahwa jumlah perokok berusia 10-18 tahun di Indonesia mencapai 5,3\%, remaja mengkonsumsi alkohol sebanyak 4\%, dan remaja mengalami masalah pertumbuhan sangat pendek mencapai 6,7\%. (RISKESDAS, 2018). Prevalensi gangguan jiwa yang ditunjukkan dengan gejala depresi pada usia 15 tahun ke atas mencapai 6,1\% yang salah satunya disebabkan oleh penyalahgunaan Napza (Kemenkes RI, 2020).

Pengabdian dilaksanakan di Panti Asuhan Bintang Terampil Kota Bengkulu yang merupakan salah satu Panti Asuhan yang ada di kota Bengkulu terletak di Jalan Merapi 6D RT 06/ RW 02 Kelurahan Panorama Kecamatan Singaran Pati Kota Bengkulu, 5 km dari Kampus IV Universitas muhammadiyah Bengkulu.

Survei awal yang dilakukan di Panti Asuhan Bintang Terampil Kota Bengkulu, didapat informasi bahwa terdapat 30 orang anak dan 5 pengurus panti. Dari observasi awal melalui wawancara terhadap 4 orang anak panti dengan beberapa pertanyaan mengenai pengetahuan tentang kesehatan remaja diketahui bahwa anak-anak belum mengetahui apa saja tentang kesehatan remaja dan mereka mengatakan belum mendapat informasi lengkap tentang kesehatan remaja.

Sehingga tim pengabdian masyarakat perlu untuk melakukan edukasi mengenai kesehatan remaja yang bertujuan memberikan pengetahuan dan pemahaman pada remaja tentang kesehatan remaja dan cara mengatasi permasalahan yang dihadapi.

\section{METODE KEGIATAN}

Pelaksanaan pengabdian kepada masyarakat dilaksanakan di Panti Asuhan Bintang Terampil dengan menggunakan metode observasi, pendidikan kesehatan berupa edukasi atau penyuluhan tentang kesehatan remaja yang dilaksanakan pada bulan Februari-Maret 2021. Observasi dilakukan untuk menentukan permasalahan apa yang dihadapi anakanak, dilanjutkan kegiatan edukasi kesehatan remaja yang akhirnya berguna dalam menghadapi masalah kesehatannya.

HASIL DAN PEMBAHASAN 


\section{Ourratism}

Pengabdian

masyarakat

dilaksankan di Panti Asuhan Bintang Terampil di mulai dari melakukan observasi terkait permasalahan kesehatan remaja yang ada. Observasi dilakukan dengan menemui beberapa orang anak remaja yang kemudian dilakukan tanya jawab seputar kesehatan remaja.

Tahapan kegiatan pengabdian masyarakat:

\section{1) Analisis Situasi}

Melakukan observasi untuk menganalisis situasi, dengan persiapan melakukan survei lokasi.

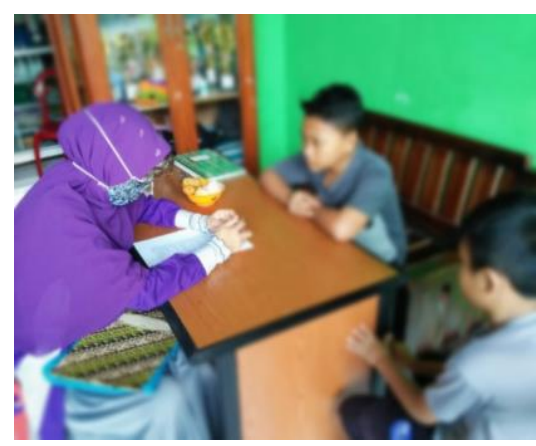

Gambar 1. Observasi tentang situasi permasalahan di Panti Asuhan Bintang Terampil

\section{2) Pelaksananaan Edukasi Kesehatan}

$$
\text { Selanjutnya Tim pengabdian }
$$
masyarakat melakukan edukasi kepada remaja berupa pemberian penyuluhan tentang kesehatan remaja. Sebelum memulai kegiatan dilakukan doa bersama untuk kelancaran kegiatan selanjutnya ketua pelaksana/ pengabdi menyampaikan maksud dan tujuan kegiatan, yang dilanjutkan dengan penyampaian materi edukasi kesehatan remaja.

$$
\begin{array}{ll}
\text { p-ISSN } & 2623-2111 \\
\text { e-ISSN } & 2623-212 X
\end{array}
$$

Adapun informasi kesehatan remaja yang diberikan adalah pengertian remaja, masalah remaja yang harus diwaspadai diantaranya bahaya merokok bagi kesehatan remaja, napza, perilaku yang salah tentang gizi, serta cara mengatasi permasalahan remaja.

Remaja mengikuti kegiatan dengan memperhatikan semua penjelasan yang disampaikan.
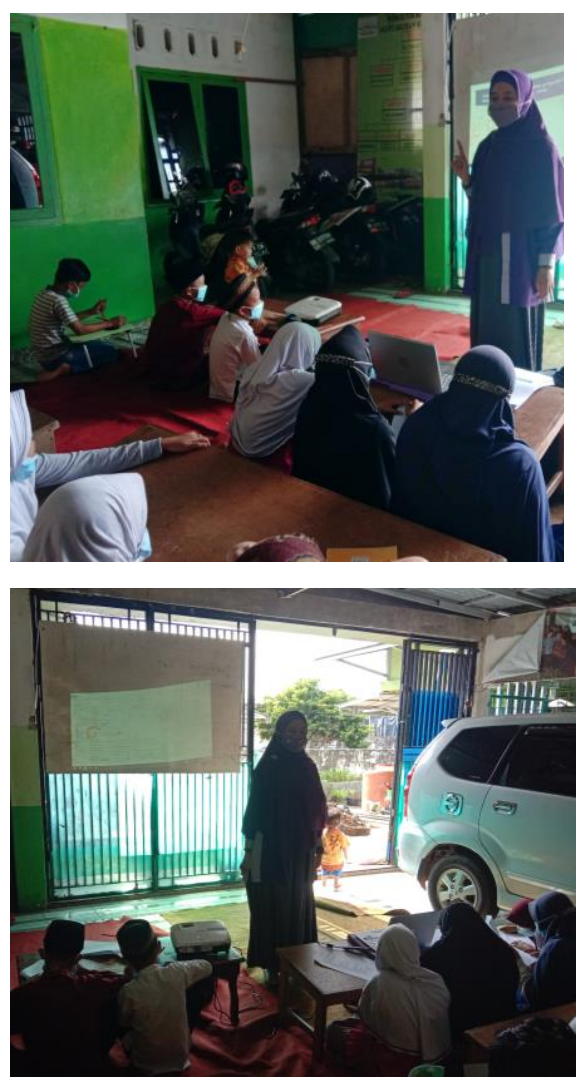

Gambar 2. Dokumentasi Edukasi Kesehatan Remaja

Remaja cenderung berperilaku berisiko. Masa remaja merupakan suatu fase perkembangan antara masa kanakkanak dan masa dewasa dimana seseorang akan mengalami banyak 
perubahan secara biologis, psikologis, maupun sosial.

Remaja 10-19 tahun berada pada masa peralihan dari kanak-kanak menjelang dewasa. Masa yang rawan dan kritis dalam perkembangan emosi dan perilaku belum stabil. Perlunya penanganan yang melibatkan semua unsur untuk dapat menangani permasalahan yang dihadapi remaja (Sartika, et al 2021).

Masalah yang sering terjadi pada remaja seperti ketidakseimbangan antara asupan kebutuhan atau kecukupan yang akan menimbulkan masalah gizi, baik itu berupa gizi lebih atau gizi kurang. Masalah gizi yang dapat terjadi pada remaja adalah gizi kurang (under weight), obesitas (over weight) dan anemia. Jumlah konsumsi energi dan zat-zat gizi lain tidak memenuhi kebutuhan tubuh menyebabkan gizi kurang sedangka kejadian gizi lebih remaja disebabkan kebiasaan makan yang kurang baik sehingga jumlah masukan energi berlebih. (Widawati, 2018).

Apabila asupan tidak tercukupi kebutuhannya maka akan memiliki peluang yang lebih besar untuk berada pada kategori status gizi kurang (Irdiana Whenny, 2017).

Hasil penelitian Widawati (2017) menunjukkan siswa dengan kebiasaan makan harian yang baik banyak memiliki status gizi normal (Widawati, 2018). Hasil penelitian yang telah dilakukan oleh Ethasari (2014) menunjukan bahwa $(30,4 \%)$ jarang sarapan dan $(5,4 \%)$ tidak pernah sarapan. Padahal, sarapan memiliki peranan penting terutama bagi anak yang bersekolah (Ethasari \& Nuryanto, 2014).

Sarapan dapat membantu dalam kosentrasi belajar disekolah sehingga, dapat medukung prestasi belajar serta dapat memenuhi kebutuhan gizi untuk aktivitas yang padat di sekolah (Arifin, L .A \& Prihanto, 2015).

Kebiasaan sarapan terlihat belum banyak dilakukan oleh responden. Hasil penelitian menunjukkan bahwa sebesar $32,7 \%$ responden yang tidak pernah sarapan walaupun sebesar $44,2 \%$ responden selalu sarapan. Permasalahan melewatkan sarapan pada anak dan remaja tidak hanya terjadi di Indonesia (Rosyidah et al., 2013).

Pemenuhan kebutuhan zat gizi karena sarapan dapat memberikan sumbangan zat gizi perharinya. Anak yang tidak sarapan akan berisiko defisiensi zat gizi. Jika hal ini berlangsung lama akan berpengaruh terhadap status gizinya. Sumbangan energi sebanyak $20 \%$ diberikan jika sesorang melakukan sarapan yang baik. Status gizi yang baik atau optimal 
akan berpengaruh bila tubuh memperoleh cukup zat gizi yang digunakan secara efisien, sehingga memungkinkan pertumbuhan fisik, pertumbuhan otak, kemampuan kerja otak (Ethasari \& Nuryanto, 2014).

Masalah terkait status gizi yaitu remaja sering membatasi konsumsi makanan dengan pola konsumsi yang tidak sesuai dengan kaidah ilmu gizi. Hasil penelitian yang dilakukan Yunita, dkk (2020) Hubungan pola diet remaja dengan status gizi menunjukkan bahwa terdapat hubungan pola diet remaja dengan status gizi (Yunita et al., 2020).

Perilaku diet berlebihan yaitu seperti konsumsi obat pencahar atau diuretik, olahraga berlebihan, pembatasan konsumsi makanan yang berlebihan, dan sengaja memuntahkan makanan memiliki risiko yang lebih besar untuk mengalami gangguan makan (Cruz-Sáez et al., 2015).

Selain itu masalah remaja yang telah mulai merokok. Merokok merupakan kegiatan yang buruk dan berbahaya bagi kesehatan tubuh karena lebih dari 4000 zat kimia beracun yang terkandung dalam rokok.

Hasil penelitian (Munir, 2018) menjelaskan bahwa lingkungan dimana dan dengan siapa mereka tinggal sangat mempengaruhi perilaku merokok dikalangan remaja. Remaja perokok yang berusia 11-15 tahun sebesar $46 \%$ berperilaku merokok secara terbuka jika mereka tinggal dirumah bebas rokok dibandingkan dengan remaja yang $76 \%$ tinggal dengan tiga atau lebih perokok.

Hal ini dikorelasikan dengan persepsi sikap yang lebih mendukung perilaku merokok didalam keluarganya. Sikap orang tua terhadap perilaku merokok mereka, 7\% dari mereka yang tinggal dengan 3 atau lebih perokok dikeluarganya, orangtua mereka tidak melakukan larangan terhadap perilaku merokok, dibandingkan dengan $1 \%$ dari mereka yang tinggal dikeluarga yang tidak merokok (Munir, 2018).

Dampak dari merokok menjadi salah satu masalah kesehatan terbesar di dunia. World Health Organization (WHO) menyatakan bahwa satu dari lima anak merokok, dan hal ini menjadi kekhawatiran karena anak-anak ini cenderung menjadi perokok seumur hidup sehingga menambah jumlah perokok dewasa di masa depan (WHO, 2020).

Remaja yang suka bereksperimentasi selalu ingin mencobacoba akan membentuk perilaku merokok. Perokok yang masih remaja memiliki status kesehatan yang buruk bila dibandingkan dengan remaja yang 
tidak merokok sama sekali (Indah Riski

Hidayati, Dewi Pujiana, 2019)

Hasil penelitian Sari

mengenai perilaku merokok di kalangan

SMA di Kota Padang menunjukkan hasil bahwa pengetahuan mereka berada pada kategori rendah sebesar $62.3 \%$, Pengetahuan merupakan faktor predisposisi yang mempengaruhi perilaku seseorang dan diharapkan mereka yang berpengetahuan tinggi akan berperilaku yang positif (Sari, 2019).

Hasil penelitian Supeno, Suroso (2015) mengenai efikasi diri di kalangan remaja menunjukkan bahwa secara parsial tidak berhubungan dengan perilaku merokok remaja laki-laki usia 12 - 15 tahun. Tidak adanya hubungan tersebut kemngkinan ada variabel lain yang lebih berhubungan erat dengan perilaku merokok remaja laki-laki usia 12-15 tahun. Misalnya, pengaruh teman sebaya, budaya merokok pada masyarakat tertentu, para perokok yang secara fisik tampak dari luar sebagai orang yang sehat-sehat saja atau tidak memiliki gangguan yang berat akibat rokok. Efikasi-diri merupakan bentuk keyakinan individu terhadap kapabilitas diri untuk meningkatkan prestasi dalam kehidupan (Supeno, 2015).

Bahaya bagi kesehatan remaja seperti masalah penyalanggunaan
NAPZA. Penyalahgunaan NAPZA (narkotika, psikotropika dan zat adiktif lainnya) merupakan permasalahan kompleks baik dilihat dari faktor penyebab maupun akibat. Rusaknya otak manusia secara permanen merupakan dampak dari narkoba bagi kesehatan, juga menimbulkan kerusakan gigi, jantung, hati, paru-paru, ginjal, lambung dan organ reproduksi manusia bahkan bayi yang dikandung dari ibu pecandu narkoba dapat terlahir secara cacat mental maupun fisik.

Dampak yang sering terjadi di tengah masyarakat dari penyalahgunaan narkoba antara lain merusak hubungan kekeluargaan, menurunkan kemampuan belajar, dan produktivitas secara drastis, sulit membedakan mana perbuatan baik maupun perbuatan buruk, perubahan perilaku menjadi perilaku anti sosial (perilaku maladaptif), gangguan kesehatan (isik dan mental), mempertinggi kecelakaan lalu lintas, tindak kekerasan atau kriminalitas lainnya (Jumaidah \& Rindu, 2017).

Penyalahgunaan Napza yang disebabkan oleh faktor internal seperti: (1) Keingintahuan yang besar untuk mencoba, tanpa berpikir panjang mengenai akibatnya, (2) Keinginan untuk mencoba-coba karena penasaran, (3) Keinginan untuk bersenang-senang atau, (4) Keinginan untuk mengikuti 
trend atau gaya, (5) Keinginan untuk diterima oleh lingkungan atau kelompok (konformitas), (6) Lari dari kebosanan, masalah atau kegetiran hidup, (7) menimbulkan ketagihan,

Ketidakmampuan menghadapi tekanan dari lingkungan atau kelompok, pergaulan untuk menggunakan Napza, dan (9) Tidak dapat berkata tidak terhadap Napza (Murtiwidayanti, 2018).

Menurut (Rachmayanie \& Rusandi, 2018), pada kegiatan pengabdian masyarakatnya tentang model pembinaan remaja tentang bahaya napza ditinjau dari sudut fisiologi otak dan sistem syaraf menjelaskan bahwa optimalisasi kedua peran pesantren melalui peningkatan kapabilitas dan aktifitas di dalamnya akan meningkatkan pemahaman bahaya narkoba yang pada akhirnya mampu menekan angka penyalahgunaan dan peredaran narkoba di kalangan remaja (Asep Suryana Abdurrahmat, 2018).

Pendidikan kesehatan dapat dilakukan dengan metode dan media yang berbeda-beda (Notoatmodjo, 2012).

Pada masa remaja, anak perempuan dan anak laki-laki menghadap tugas perkembangan yang menantang, seperti menyesuaikan diri dengan kelompok teman sebaya, membedakan dari keluarga dan memajukan pembentukan identitas.
Hasil penelitian Racmayanie, Arli (2018) menjelasakan bahwa remaja dengan perilaku menyimpang lebih cenderung menggunakan coping disengagement dalam menghadapi masalah dalam hidupnya, lebih tepatnya melarikan diri, menghindari dan menjauhkan dari stressor (Rachmayanie \& Rusandi, 2018). Permasalahan harus dihadapi dengan berada dilingkungan pertemanan yang baik atau memberikan dampak positif, bersama teman yang setia dan dapat dipercaya, serta tingkatkan ibadah.

3) Tahapan sesi tanya jawab

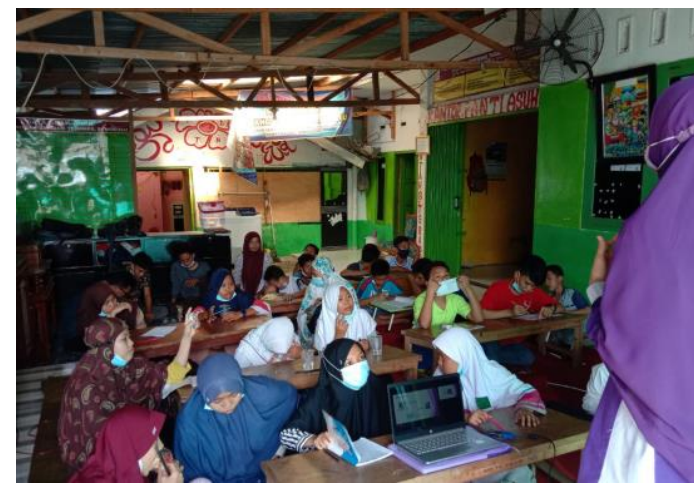

Gambar 3. Dokumentasi Sesi Tanya Jawab setelah Edukasi Kesehatan Remaja

Selanjutnya dilakukan sesi tanya jawab kepada remaja tentang hasil edukasi yang diberikan. Kegiatan ini bertujuan untuk mengetahui sejauh mana remaja telah memahami materi yang telah disampaikan seputar kesehatan remaja.

Remaja terlihat antusias saat mengikuti kegiatan, hasil tanya jawab, remaja menjadi tahu apa yang dimaksud 
remaja, dari sebelumnya remaja belum mengetahui apa itu remaja hingga cara dalam mengatasi masalah kesehatan remaja. Terlihat pertanyaan yang diajukan, remaja mampu memberikan jawaban yang tepat. Hasil kuesioner yang diberikan, remaja telah mampu menyelesaikan pertanyaan dengan jawaban benar, ada peningkatkan dari sebelum dilakukan edukasi pada remaja.

Pendidikan kesehatan bertujuan agar orang mampu menerapkan masalah dan kebutuhan mereka sendiri, mampu memahami apa yg dapat mereka lakukan terhadap masalahnya, dengan sumber daya yg ada pada mereka ditambah dengan dukungan dari luar, dan mampu memutuskan kegiatan yg tepat guna untuk meningkatkan taraf hidup sehat dan kesejahteraan masyarakat (Mubarak, 2012).

4) Penutupan

Tahapan terakhir kegiatan pengabdian masyarakat dengan foto Bersama. Remaja di Panti Asuhan Bintang terampil Kota Bengkulu.

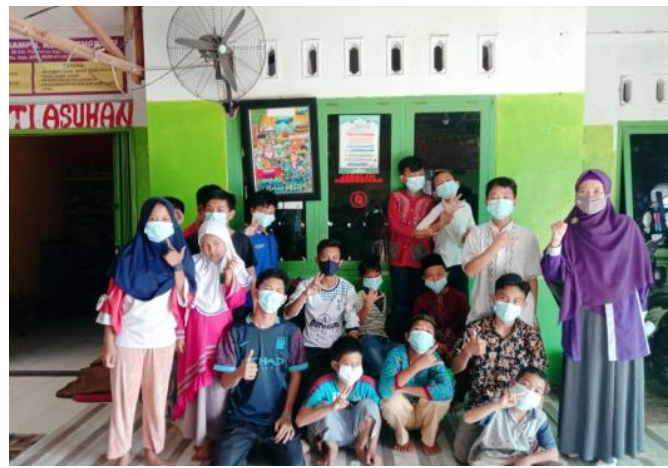

Gambar 4. Dokumentasi Bersama remaja Panti

\section{PENUTUP}

Berdasarkan hasil pengabdian kepada masyarakat berupa pemberian edukasi tentang kesehatan remaja pada remaja di Panti Bintang Terampil Kota Bengkulu, dapat disimpulkan:

a) Remaja berpartisipasi pada setiap kegiatan pengabdian masyarakat dari saat analisis situasi permasalahan yang ada hingga sesi tanya jawab.

b) Remaja antusias mengikuti kegiatan pengabdian masyarakat berupa pemberian edukasi kesehatan remaja.

c) Kegiatan pengabdian masyarakat telah berjalan seesuai tahapan, sesuai dengan yang ditargetkan adanya peningkatan pengetahuan dan pemahaman remaja tentang kesehatan remaja setelah dilakukan eduksi.

\section{DAFTAR PUSTAKA}

Arifin, L .A \& Prihanto, J. . (2015). Hubungan Sarapan Pagi denagn tingkat Konsentrasi Siswa di Sekolah. Jurnal Pendidikan Olahraga dan Kesehatan, 3(1), 203-207.

Asep Suryana Abdurrahmat, N. L. (2018). Model Pembinaan Remaja Tentang Bahaya Napza Ditinjau dari Sudut Fisiologi Otak dan Sistem Syara. 4(1), 29-33. 
Cruz-Sáez, S., Pascual, A., Salaberria, K., Etxebarria, I., \& Echeburúa, E. (2015). Risky eating behaviors and beliefs among adolescent girls. Journal of Health Psychology, 20(2), 154-163. https://doi.org/10.1177/1359105313 500683

Ethasari, R. K., \& Nuryanto, N. (2014). Hubungan Antara Kebiasaan Sarapan Dengan Kesegaran Jasmani Dan Status Gizi Pada Anak Sekolah Dasar Di Sd Negeri Padangsari 02 Banyumanik. Journal of Nutrition College, 3(3), 346-352. https://doi.org/10.14710/jnc.v3i3.65 87

Indah Riski Hidayati, Dewi Pujiana, M. F. (2019). Pengaruh Pendidikan Kesehatan Terhadap Pengetahuan Dan Sikap Siswa Tentang Bahaya Merokok Kelas XI SMA Yayasan Wanita Kereta Api Palembang Tahun 2019. 12(2), 125-135.

Irdiana Whenny. (2017). Hubungan Kebiasaan Sarapan dan Asupan Zat Gizi dengan Status Gizi Siswi SMAN 3 Surabaya. Amerta Nutrition, $\quad 1(3), \quad 227$. https://doi.org/10.20473/amnt.v1i3. 6249

Jumaidah, J., \& Rindu, R. (2017). Perilaku Pencegahan

Penyalahgunaan Narkoba Pada Remaja Di Wilayah Kecamatan Sukmajaya, Depok. Jurnal Ilmiah Kesehatan, 16(3), 42-49. https://doi.org/10.33221/jikes.v16i3 .38

Kemenkes RI. (2019). Profil Kesehatan Indonesia 2018 [Indonesia Health Profile 2018].

Kemenkes RI. (2020). Profil Kesehatan Indonesia Tahun 2019. In Kementerian Kesehatan RI. https://doi.org/10.1017/CBO978110 7415324.004

Mubarak. (2012). Promosi kesehatan: Sebuah pengantar proses belajar mengajar dalam pendidikan.
Munir, M. (2018). Pengetahuan dan Sikap Remaja Tentang Risiko Merokok pada Santri Mahasiswa di Asrama UIN Sunan Ampel Surabaya. Klorofil, 1(2), 93-104.

Murtiwidayanti, S. Y. (2018). Sikap dan Kepedulian Remaja dalam Penanggulangan Penyalahgunaan Narkoba. Jurnal PKS, Volume 17, 49.

Notoatmodjo, S. (2012). Pendidikan dan Ilmu Perilaku Kesehatan. Rineka Cipta.

Rachmayanie, R., \& Rusandi, M. A. (2018). Strategi coping remaja pada perilaku menyimpang. Seminar Nasional Bimbingan Dan Konseling Di Perguruan Tinggi, April, 1-9.

RISKESDAS. (2018). Laporan Nasional Riskesdas 2018_FINAL. In Badan Penelitian dan Pengembangan Kesehatan (hal. 198).

Rosyidah, Z., Ririn Andrias, D., \& Gizi Kesehatan Fakultas Kesehatan, D. (2013). Jumlah Uang Saku Dan Kebiasaan Melewatkan Sarapan Berhubungan Dengan Status Gizi Lebih Anak Sekolah Dasar. 1-6.

Sari, a. (2019). Perilaku Merokok di Kalangan Siswa Sekolah Menengah Atas di Kota Padang. Jurnal Ilmiah Kesehatan Masyarakat, 11, 238244.

Sartika, A., Oktarianita, O., \& Padila, P. (2021). Penyuluhan terhadap Pengetahuan Remaja tentang PKPR. Journal of Telenursing (JOTING), 3(1), 171-176. https://doi.org/https://doi.org/10.31 539/joting.v3i1.2192

Supeno, S. (2015). Kematangan Emosi, Efikasi Diri dan Perilaku Merokok Remaja Laki-Laki Usia 12-15 Tahun. Persona: Jurnal Psikologi Indonesia, 4(03), 288-295. https://doi.org/10.30996/persona.v4 i03.723

WHO. (2020). Organization World Health.

Widawati. (2018). Gambaran Kebiasaan 
Makan dan Status Gizi Remaja di SMAN 1 Kampar tahun 2017. Jurnal Gizi (Nutritions Journal), 2(2), 146-159.

Yunita, F. A., Eka, A., Yuneta, N., \&
Sutisna, E. (2020). Hubungan Pola Diet Remaja Dengan Status Gizi. 8(2), 27-32. 